\title{
Avenues of archetype analysis: roots, achievements, and next steps in sustainability research
}

\author{
Klaus Eisenack $^{1}$, Christoph Oberlack $^{2,3}$ and Diana Sietz ${ }^{4,5}$
}

\begin{abstract}
Recent years have seen a proliferation of studies that use archetype analysis to better understand and to foster transitions toward sustainability. This growing literature reveals a common methodological ground, as well as a variety of perspectives and practices. In this paper, we provide an historical overview of the roots of archetype analysis from ancient philosophy to recent sustainability science. We thereby derive core features of the archetype approach, which we frame by eight propositions. We then introduce the Special Feature, "Archetype Analysis in Sustainability Research," which offers a consolidated understanding of the approach, a portfolio of methods, and quality criteria, as well as cutting-edge applications. By reflecting on the Special Feature's empirical and methodological contributions, we hope that the showcased advances, exemplary applications, and conceptual clarifications will help to design future research that contributes to collaborative learning on archetypical patterns leading toward sustainability. The paper concludes with an outlook highlighting central directions for the next wave of archetype analyses.
\end{abstract}

Key Words: biodiversity; building-block; case studies; classification; climate change; diagnostic approach; land-use; pattern; scenario analysis; social-ecological system; transfer of solutions; typology; vulnerability.

\section{INTRODUCTION}

When searching for ways to achieve sustainability, scholars are confronted by the diversity of local and regional factors and processes, which are often interlocked or telecoupled in complicated ways. How can sustainability problems and solutions, in all their diversity, be explained? To address such challenges for research and practice, recent years have seen the rise of archetype analysis as a novel approach in sustainability research (Oberlack et al. 2019).

If sustainability research does not take care of each case's specific features, we might continue on the track of blueprint solutions. Such panaceas are problematic if they disregard socio-cultural, political-institutional, economic, and ecological particularities of the cases and contexts in which they guide action (Ostrom et al. 2007). On the other hand, there are common patterns around the world that repeatedly shape the (un)sustainability of socialecological systems. For example, Sietz et al. (2011) take the zaï technique, a traditional land rehabilitation approach used in Burkina Faso. This is a region-specific solution that has helped to improve degraded soils, food production, and well-being and to reduce rural out-migration. Yet, this raises the question as to whether the zaï technique is replicable to restore farmlands elsewhere. This highlights the importance of identifying the relevant social-ecological similarities among various locations to assess such a transfer of solutions.

To address questions of similarity and replicability in a rigorous way, archetype analysis can draw from a broad portfolio of methods (Sietz et al. 2019). Knowledge of archetypical patterns across cases has supported a better understanding of key sustainability challenges related to land use, climate change adaptation, vulnerability, large-scale land acquisition, ecological footprints, and regional development, among others. Archetypes featured prominently in the UNEP's (2007) Global Environment Outlook 4. Currently, the development of best practices for archetype analysis is one frontier of innovation (Eisenack et al.
2019). On the following pages, we provide a novel consolidated understanding of the approach, including a sketch of its emergence and core ideas. Then we introduce the Special Feature, "Archetype Analysis in Sustainability Research" of Ecology and Society. This Special Feature contains several conceptual and methodological papers, and it showcases cutting-edge examples of archetype analyses. We hope that this collection will help readers to judge the promises and pitfalls of the archetype approach.

"Archetype analysis investigates recurrent patterns of the phenomenon of interest at an intermediate level of abstraction to identify multiple models that explain the phenomenon under particular conditions"(Oberlack et al. 2019). A core starting point is the assumption that it is useful to consider multiple explanations, theories, or models in parallel. An archetype analysis thus determines or studies a suite of (i.e., multiple) patterns, each called an archetype. A single archetype would not be able to explain all instances of a phenomenon (Eisenack et al. 2006a). If multiple archetypes on the same issue are not admitted, i.e., if research aims at a general law that holds for the complete universe of cases, research risks a meaningless overgeneralization. Furthermore, not admitting a suite of multiple archetypes might hamper interdisciplinary collaboration when a common epistemological or ontological base is not available (Spash 2012). We do not consider archetype analysis as a method because it is open to many empirical and analytical techniques. The term "approach" seems more appropriate because patterns can be analyzed using different qualitative, quantitative, and mixed methods (Sietz et al. 2019). Implicit in this understanding is a focus on cases as units of analysis. What makes a case depends on the phenomenon of interest or research question: it may be a region, a grid cell, an organization, a conflict, a household, a land or food system, or a kind of contract, for example. Whereas some archetype analyses deal with a large number of cases, others provide rich detail on a small number.

${ }^{1}$ Resource Economics Group, Humboldt Universität zu Berlin, Germany, ${ }^{2}$ Centre for Development and Environment (CDE), University of Bern, Bern, Switzerland, ${ }^{3}$ Institute of Geography, University of Bern, Bern, Switzerland, ${ }^{4}$ Thünen Institute of Biodiversity, Braunschweig, Germany, ${ }^{5}$ Potsdam Institute for Climate Impact Research (PIK), Member of Leibniz Association, Potsdam, Germany 


\section{EVOLUTION OF ARCHETYPE ANALYSIS AND RELATED APPROACHES}

The basic ingredients of archetypes thinking as outlined in the previous section are not totally new. The motivation to distil general knowledge by comparative analysis is at least as old as modern science. The particular feature of archetype analysis is to understand the sustainability of social-ecological systems or interventions in a way as general as possible, but fine-grained enough to account for important case-specific particularities. In the following, we outline how related concepts have been used in the history of science and what ideas are shared with related ways of thought in sustainability research.

Eight propositions on archetype analysis

Recent archetype analyses have tended to take one of two approaches: developing case typologies, i.e., classification of cases, or identifying building blocks that may be (re)combined in different ways to explain individual cases (Oberlack et al. 2019). We argue that the combination of both takes is the most fruitful avenue to follow, because case typologies are frequently a good starting point for analysis, and building blocks admit to economize on the number of archetypes in a suite (Eisenack et al. 2019). We start with a summary of eight propositions about comprehensive archetype analysis, i.e., an analysis aiming at high standards, which emphasizes this combination (see Table 1; for more details on the concepts in the table, see Eisenack et al. 2006a, 2019, Oberlack et al. 2019, Sietz et al. 2019; see also http://www. archetype-analysis.net). One important premise behind the propositions should be made explicit: archetype analysis does not aim to collect a universal set of patterns that matter for all kinds of scientific inquiry. Instead, each archetype analysis is specific for a (set of) research question(s) or application(s).

Table 1. Core propositions on comprehensive archetype analysis.

\begin{tabular}{|c|c|}
\hline $\begin{array}{l}\text { Num- } \\
\text { ber }\end{array}$ & Proposition \\
\hline 1 & $\begin{array}{l}\text { Archetype analysis is a comparative approach to deal with a } \\
\text { medium or large number of heterogeneous cases. }\end{array}$ \\
\hline 2 & $\begin{array}{l}\text { An archetype analysis produces a suite of archetypes (and not a } \\
\text { universal law). }\end{array}$ \\
\hline 3 & $\begin{array}{l}\text { An archetype characterizes components of cases (e.g., actors, } \\
\text { processes, effects, or sub-systems), that re-occur in multiple (but } \\
\text { not necessarily all) cases. }\end{array}$ \\
\hline 4 & $\begin{array}{l}\text { Archetypes function as building blocks that can be combined in } \\
\text { different ways to explain individual cases. }\end{array}$ \\
\hline 5 & $\begin{array}{l}\text { A comprehensive archetype analysis characterizes each archetype } \\
\text { by three elements: (i) a configuration of attributes; (ii) a theory or } \\
\text { hypothesis that explain the relation between the attributes; (iii) a } \\
\text { set of cases where it holds. }\end{array}$ \\
\hline 6 & $\begin{array}{l}\text { All archetypes in a suite characterize cases and configurations by } \\
\text { referring to a common vocabulary of attributes (but each } \\
\text { archetype does not need to use it completely). }\end{array}$ \\
\hline 7 & $\begin{array}{l}\text { Attributes and archetypes are formulated on an intermediate level } \\
\text { of abstraction. }\end{array}$ \\
\hline 8 & $\begin{array}{l}\text { Archetypes are analytical or mental constructs, but are not } \\
\text { necessarily material or functional mechanisms or systems. }\end{array}$ \\
\hline
\end{tabular}

\section{Early roots}

Aristotle (fourth century BC) was likely not the first to sort particular cases into (more abstract) different kinds, types, or classes, where each class has something in common. Archetype analysis classifies cases by presuming that there is likely no single mechanism behind all of them (prop. 2). For Aristotle, "kinds" are characterized by properties that are essential to all contained individuals, while other properties are accidental (Aristotle, Metaphysics). Classification only makes sense if there are multiple classes (prop. 2, 3). Things can be organized in a hierarchy of concepts with different degrees of generality or abstraction (Aristotle, Organon; cf. prop. 7). When scholars address a (new) set of phenomena, it has always been common to first develop classifications, for instance the Linneean taxonomy of living beings, the periodic table of chemical elements, or the classification of stars by the astronomer Angelo Secchi. The semantic of classes and concepts can be made precise by distinguishing the extension and intension of a concept (Carnap 1956). Whereas the former is the set of all particular "objects" (members) of the concept (e.g., all cases sharing a particular attribute), the latter is the set of properties or attributes that all objects belonging to the concept share. In archetype analyses, when cases (extensions) are described, we call the properties used (intension) the "attributes" (prop. 6), and aim to find recurring configurations of those attributes (prop. 5). Depending on whether the attributes' extension is larger or smaller, archetypes can differ in how general or abstract they are (prop. 7).

John Locke (since 1689) was, to our knowledge, the first to work with the term "archetype," as "patterns or models from which they [real ideas] are copied" (Locke 1689, An Essay Concerning Human Understanding). Because classification is essential for archetype analysis, an obvious question follows: What is different between an archetype and a type? For Locke, "archetypes are made by the mind to serve as standards for classifying and naming things" (prop. 8). Such classes are required if humans aim at knowing an overly complicated world of particulars. Classes do not serve this purpose if they contain just single particulars (prop. 3 ). Because archetypes are made by the mind, Locke rejects essential properties. George Berkeley (1710, A Treatise Concerning the Principles of Human Knowledge) even understands them as purely subjective. For Locke, archetypes are not arbitrary because they need to "conform to the real being and existence of things". Although there are many ways to classify one same subject matter (prop. 2), Locke's conception of archetypes can be understood as constrained and convergent (Anstey 2011); they are thus more than arbitrary types, but need to fit to theoretical and empirical constraints. Archetypes, as we understand them, might be characterized as "cluster kinds" (Boyd 1991): configurations of attributes that are held together by some internal or external mechanisms. They are thus not arbitrary and each archetype can be underpinned by a theory to explain such a mechanism (prop. 5).

Immanuel Kant (since 1781) uses the term "intellectus archetypus," yet in another way than we do, to denote the idea of a divine being or perfectly rational mode of reasoning (Kant 1781, Critique of Pure Reason). In English translations, the term "archetypal ideas" is also used when Kant discusses biological kinds (Kant 1790, Critique of Judgement). Each individual organism from a species or genus might be conceived as being a copy of a common Urbild (archetype). Kant understands these archetypes only as a heuristic that is helpful for reasoning.

Carl Jung (since 1902) developed well-known psychological archetypes of personal traits. They refer to common symbolic patterns that are inscribed into the collective unconscious. This 
is a more domain-specific understanding in psychology than the one used in sustainability research. Furthermore, archetype analysis in sustainability research does not aim to reveal universal patterns (prop. 1).

Middle-range theories (since 1968) were proposed for the social sciences (Merton 1968) to contrast grand theories or general laws (prop. 2). Middle-range theories aim at explaining empirical regularities, but within a clearly delimited range of conditions (Meyfroidt et al. 2018). Yet, such theorizing "always involves more than the (detailed) description of single cases" (Esser 2010:1; i.e., prop. 3 ). This can be done by hypothesizing mechanisms or causal relations (prop. 5). The mechanisms should play a role for multiple cases. Although some scholars envisaged a research program to come up, over time, with a coherent collection of middle-range theories to cover large parts of social inquiry, this vision has not gained traction (Esser 2002). Yet, middle-range theories are developed for specific research questions or objectives (prop. 1). Furthermore, Esser (2002) demonstrates how different mechanisms from social theory (see also Elster 2006) can be combined in a modular way (prop. 4), tailored to obtain middlerange theories for specific issues. Archetype analysis is one approach to develop middle-range theories (Magliocca et al. 2018, Meyfroidt et al. 2018). Vice versa, middle-range theories can offer explanations that characterize archetypes (prop. 5).

The Pattern Language (Alexander et al. 1977) for architecture is an inspiring approach related to our conceptualization of archetypes. Taking a design perspective, it does not provide a universal theory of architecture, but provides a large collection of architectural forms and patterns that frequently recur in buildings (e.g., "cascade of roofs," "roof garden," "six-foot balcony"). Each pattern is supplied with an empirical or theoretical justification (prop. 5). For new architectural projects, the authors suggest to choose some (but not all) of the patterns, like choosing words from a language when you compose a text (prop. 6). The patterns serve as building-blocks, because they can be combined in different ways for idiosyncratic projects (prop. 4).

Other related streams of thought, which are not covered by our above propositions, may warrant more study in the future. The ordinary language understanding of "pattern" might well be a good starting point (e.g., Kelso 1997), because it also admits classification with non-crisp or fuzzy boundaries. We might say that two cases belong to the same pattern if they are not similar in kind, but in degree. Also, ideal types of Weber (1922) admit comparison by degree. Recurrence of archetypes might also be understood by family resemblance (Wittgenstein 1953).

\section{Related branches in sustainability research}

Since the 1980s, some approaches similar to archetype analysis have been suggested, partly being influential in sustainability research and in the development of archetype analysis. Configurational approaches (since 1987) aim at identifying attributes that tend to co-occur in the case universe, but not necessarily in all cases (prop. 3). Ragin's (1987) comparative method, for instance, takes account of idiosyncratic properties of cases, but also identifies (sets of) conditions that are sufficient for the outcome of interest in one or more cases (prop. 3, prop. 7). The method is strong in the study of a medium number of cases where inferential statistics are not appropriate (prop. 1). Although each case is studied in depth (also to provide explanations for such conditions, prop. 5), all cases are also more abstractly described by a common set of conditions (yet, prop. 6 does not hold, because every case needs to be described by the complete set of conditions). Qualitative comparative analysis (QCA; see also Schneider and Wagemann 2012), probably the most prominent configurational approach, derives a general Boolean formula from the data. QCA outputs expressions in disjunctive normal form, i.e., like "the outcome holds in all cases where A OR B OR C...", where a list of alternative (sets of) conditions (A, B, C, ...) is linked by the Boolean "OR" operator. This is called equifinality, i.e., that different (sets of) conditions can lead to the same outcome (prop. 2).

System archetypes (since 1990) have been developed in the domain of systems dynamics (Senge 1990, Wolstenholme 2003). Each archetype (prop. 2) describes a common management problem, and is formulated by using a causal-loop diagram (prop. 5). Examples are the "Tragedy of the Commons" or "Limits to Growth". The variables in the diagrams need to be quite abstract in order to be applicable in many situations (e.g., "Resources," "Effort," "Capacity"), leading to interesting discussions on conceiving generic structure (Lane and Smart 1996). This requires the analyst to give variables a more concrete meaning, e.g., an indicator, when applying a system archetype (prop. 7). Causal loops characterize mechanisms that determine how variables change over time, a possibility not used by many archetype analyses so far. System archetypes further assume that different real-world problems, which are appropriately captured by the same archetype, can be addressed by similar generic solutions, but that not all real-world problems are of the same kind (prop. 3).

Syndromes of global change (since 1994), inspired by the medical metaphor, were proposed by the German Advisory Council on Global Change (WBGU 1994) to map configurations of cooccurring factors (symptoms) that constitute syndromes. Syndromes decompose global change dynamics into coevolutionary trends that appear repeatedly in typical combinations (Lüdeke et al. 2004). A suite of 16 syndromes (prop. 2) were identified, including "Urban Sprawl," "Sahel Syndrome," or "Overexploitation" (cf. Kropp et al. 2006, Sietz et al. 2006, Reckien et al. 2011) that reappear in many regions (prop. 3). Drawing on the same list of about 80 symptoms (prop. 6), each syndrome is characterized by a set of closely related symptoms (prop. 5). The dynamics of some syndromes have been analyzed with qualitative differential equations (e.g., Petschel-Held and Lüdeke 2001, Eisenack et al. 2006b, Sietz et al. 2006, Reckien et al. 2011). Symptoms are formulated in a general way, enabling comparison across regions (prop. 7). For instance, "degradation of natural resources" can refer to forest biomass loss in one region and declining soil quality in another. Moreover, in several regions, multiple syndromes are diagnosed, making them building blocks that can appear in different combinations (prop. 4). Although they are quite comprehensive, syndromes of global change emphasize biophysical, demographic, and economic over institutional factors, limiting the direct analysis of institutional drivers of change and options for a transformation toward sustainability. 
The Diagnostic approach and the SES Framework (since 2002) were also inspired by the medical metaphor (Young 2002, Young et al. 2006). The approaches highlight that sustainability problems are too diverse (prop. 1) to be addressed by simple institutional "panaceas" (like private property, Ostrom 2007, Ostrom et al. 2007). They aim at "identifying key features of needs for governance on a case-by-case basis ... in order to ensure a good match ... for ... the institutional response" (Young 2019). Yet, institutional design principles might be transferred between cases if they are diagnosed in the same way (prop. 2, 3; Cox et al. 2010). This requires partitioning the universe of cases (prop. 2). The Social-Ecological Systems framework (SES; Ostrom 2009, McGinnis and Ostrom 2014) brings different levels of abstraction (prop. 7) more to the center. The framework proposes a nested list of variables that are considered to be commonly important for many social-ecological-technical systems (a common vocabulary, prop. 6). Each variable in the most abstract "tier" (e. g., "resource units," "governance system") is refined to a more concrete set of about 3-9 variables (e.g., "number of resource units," "monitoring and sanctioning rules"). Not all variables are relevant for a particular case, and they can be further refined to higher tier variables if required. First archetype studies build on this set of variables (Oberlack and Eisenack 2018, Gotgelf et al. 2020, Villamayor-Tomas et al. 2020a). Configurations of SES variables can be tied to theoretical explanations (prop. 5; cf. Cox et al. 2016).

Causes of land use change (since 2003) have been studied using meta-analyses of heterogeneous case studies (prop. 1). These synthesize recurrent drivers and outcomes of desertification, deforestation, agricultural intensification, and food insecurity (Rudel and Roper 1997, Lambin et al. 2003, Geist and Lambin 2004, Keys and McConnell 2005, Misselhorn 2005). Like archetype analysis, this approach balances descriptive richness of local case studies with a general understanding of the issue at stake. These studies reveal multiple patterns, created by differently interwoven causal factors. Because not every case is explained by the same combination of factors, a whole suite of patterns is derived (prop. 2). Examples are combinations of causal factors, such as agricultural activity, increasing aridity, and infrastructure extension. These factors are formulated on an intermediate abstraction level, meaning that their specification may differ between locations and regions (prop. 7). The factors' importance is assessed by their frequency. Although Lambin et al. (2003) and Geist and Lambin (2004) use a consolidated list of such factors, not every factor needs to play a role in every pattern. Instead, the factors function like a vocabulary to choose from when any of the patterns is described (prop. 6).

Archetypes of vulnerability (since 2007), synthesized in the Global Environment Outlook GEO-4 (UNEP 2007), identify recurrent conditions from a multitude of observations to highlight typical vulnerability-creating mechanisms in the face of environmental and socioeconomic change. GEO-4 revealed a suite of seven archetypes of vulnerability (prop. 2), each combining recurrent factors that endanger the environmental and living conditions in particular regions (prop. 3), e.g., related to global commons, contaminated sites, energy production, or urbanization in coastal zones. The archetypes confirm essential mechanisms described by the syndromes of global change. For instance, the Dryland Archetype includes the poverty- degradation spiral, the typical mechanism of the Sahel Syndrome (Petschel-Held et al. 1999). Methodologically, basic vulnerabilitycreating conditions were synthesized from the literature and hypotheses about mechanisms were deduced (prop. 5). Causal variables were expressed by quantitative indicators and clustered (prop. 5) in mutually exclusive vulnerability profiles (Sietz et al. 2011, Kok et al. 2016). The vulnerability profiles were further differentiated at local scales (Sietz et al. 2012, Vidal Merino et al. 2019) and nested continental scales (Sietz et al. 2017); they thus navigate different scales of abstraction (prop. 7). Policy implications and entry-points for improvement were discussed for each vulnerability profile, and the transferability of findings was demonstrated in combination with ground-truthing (testing and contextualizing) against local case studies.

After having compared these influential approaches in light of the core propositions, we now relate this conceptual consolidation of archetype analysis to the genesis and main insights of this Special Feature.

\section{SPECIAL FEATURE ON ARCHETYPE ANALYSIS IN SUSTAINABILITY RESEARCH}

The rapid growth and diversification of studies using archetype analysis has generated variations and inconsistencies about using the approach (Oberlack et al. 2019). This Special Feature on "Archetype Analysis in Sustainability Research" was thus created to confront several major research challenges, including a lack of consensus on the multiple and precise meanings of the approach in sustainability research, on the portfolio of methods, and on best practice examples for high-quality archetype analysis. It thus aims to,

1. Take stock of examples, opportunities, pitfalls, and methods;

2. Push current methodological frontiers by encouraging methodological debate and cutting-edge applications;

3. Contribute to sustainability research by presenting new applications of archetype analysis;

4. Open new avenues for a next generation of archetype analysis.

To achieve these objectives, an ongoing series of international, open research workshops on archetype analysis in sustainability research has been created (Bern 2017, Berlin 2018, Olomouc 2019, Stockholm/online 2021; see http://www.archetype-analysis.net for up-to-date information). Taken together, the efforts of hundreds of scholars from various takes on sustainability research have surprisingly converged in recent years in developing the emerging approach of archetype analysis.

Overall, 16 papers from international author teams appear in this Special Feature, which cover different sustainability issues (see Table 2 for a summary). Three opening synthesis papers provide an overview from different angles. Oberlack et al. (2019) provide a consolidated perspective on the multiple meanings, motivations, and policy relevance of archetype analysis, based on the literature so far. Eisenack et al. (2019) analyze main challenges for archetype analyses in order to develop quality criteria and to improve future archetype analyses. Sietz et al. (2019) synthesize the portfolio of methods currently used for the approach, and highlight the strengths, weaknesses, and analytical frontiers in employing them 
Table 2. Summary of contributions.

\begin{tabular}{|c|c|c|c|c|c|c|c|c|}
\hline Paper & Title & Issue & Sources & $\begin{array}{l}\text { Function } \\
\text { of arche- } \\
\text { type } \\
\text { analysis }\end{array}$ & $\begin{array}{l}\text { Typology } \\
\text { or building } \\
\text { blocks }\end{array}$ & $\begin{array}{l}\text { Analytical } \\
\text { methods }\end{array}$ & $\begin{array}{l}\text { Transferab- } \\
\text { ility/ } \\
\text { replicability } \\
\text { addressed }\end{array}$ & $\begin{array}{l}\text { No. and kind of } \\
\text { cases }\end{array}$ \\
\hline $\begin{array}{l}\text { Oberlack et al. } \\
2019\end{array}$ & $\begin{array}{l}\text { Archetype analysis in } \\
\text { sustainability research: meanings, } \\
\text { motivations, and evidence-based } \\
\text { policy making }\end{array}$ & $\begin{array}{l}\text { Fundamentals of } \\
\text { archetype } \\
\text { analysis }\end{array}$ & Synthesis & NA & NA & NA & Yes & NA \\
\hline $\begin{array}{l}\text { Eisenack et al. } \\
2019\end{array}$ & $\begin{array}{l}\text { Design and quality criteria for } \\
\text { archetype analysis }\end{array}$ & $\begin{array}{l}\text { Fundamentals of } \\
\text { archetype } \\
\text { analysis }\end{array}$ & Synthesis & NA & NA & NA & Yes & NA \\
\hline Sietz et al. 2019 & $\begin{array}{l}\text { Archetype analysis in } \\
\text { sustainability research: } \\
\text { methodological portfolio and } \\
\text { analytical frontiers }\end{array}$ & $\begin{array}{l}\text { Fundamentals of } \\
\text { archetype } \\
\text { analysis }\end{array}$ & Synthesis & NA & NA & NA & Yes & NA \\
\hline $\begin{array}{l}\text { Harrison et al. } \\
2019\end{array}$ & $\begin{array}{l}\text { Synthesizing plausible futures for } \\
\text { biodiversity and ecosystem } \\
\text { services in Europe and Central } \\
\text { Asia using scenario archetypes }\end{array}$ & $\begin{array}{l}\text { Biodiversity; } \\
\text { science-policy } \\
\text { interface }\end{array}$ & $\begin{array}{l}\text { Meta-study } \\
\text { and expert } \\
\text { assessment }\end{array}$ & $\begin{array}{l}\text { Scenario } \\
\text { analysis }\end{array}$ & $\begin{array}{l}\text { Case } \\
\text { typology }\end{array}$ & Qualitative & NA & Scenarios (436) \\
\hline Sitas et al. 2019 & $\begin{array}{l}\text { Exploring the usefulness of } \\
\text { scenario archetypes in science- } \\
\text { policy processes: experience across } \\
\text { IPBES assessments }\end{array}$ & $\begin{array}{l}\text { Biodiversity; } \\
\text { science-policy } \\
\text { interface }\end{array}$ & $\begin{array}{l}\text { Expert } \\
\text { assessment }\end{array}$ & $\begin{array}{l}\text { Scenario } \\
\text { analysis }\end{array}$ & NA & Qualitative & NA & NA \\
\hline Pedde et al. 2019 & $\begin{array}{l}\text { Archetyping shared } \\
\text { socioeconomic pathways across } \\
\text { scales: an application to central } \\
\text { Asia and European case studies }\end{array}$ & $\begin{array}{l}\text { Socio-economic } \\
\text { development }\end{array}$ & $\begin{array}{l}\text { Expert } \\
\text { assessment }\end{array}$ & $\begin{array}{l}\text { Scenario } \\
\text { analysis }\end{array}$ & Both & Qualitative & No & Pathways (4) \\
\hline $\begin{array}{l}\text { Horcea-Milcu et } \\
\text { al. } 2020\end{array}$ & $\begin{array}{l}\text { Research pathways to foster } \\
\text { transformation: linking } \\
\text { sustainability science and social- } \\
\text { ecological systems research }\end{array}$ & $\begin{array}{l}\text { Sustainability } \\
\text { transformation }\end{array}$ & $\begin{array}{l}\text { Meta- } \\
\text { analysis }\end{array}$ & Induction & $\begin{array}{l}\text { Clusters } \\
\text { (not } \\
\text { mutually } \\
\text { exclusive) }\end{array}$ & Mixed & No & Publications (51) \\
\hline $\begin{array}{l}\text { Tribaldos et al. } \\
2020\end{array}$ & $\begin{array}{l}\text { Impact through participatory } \\
\text { research approaches: an archetype } \\
\text { analysis }\end{array}$ & $\begin{array}{l}\text { Participatory } \\
\text { research }\end{array}$ & $\begin{array}{l}\text { Meta- } \\
\text { analysis }\end{array}$ & Induction & $\begin{array}{l}\text { Building } \\
\text { blocks }\end{array}$ & Qualitative & Implicit & Publications (26) \\
\hline Newig et al. 2019 & $\begin{array}{l}\text { Sustainability through } \\
\text { institutional failure and decline? } \\
\text { Archetypes of productive } \\
\text { pathways }\end{array}$ & $\begin{array}{l}\text { Institutional } \\
\text { failure and } \\
\text { decline }\end{array}$ & Theoretical & Deduction & $\begin{array}{l}\text { Building- } \\
\text { blocks }\end{array}$ & NA & No & NA \\
\hline Moser et al. 2019 & $\begin{array}{l}\text { Adaptation finance archetypes: } \\
\text { local governments' persistent } \\
\text { challenges of funding adaptation } \\
\text { to climate change and ways to } \\
\text { overcome them }\end{array}$ & $\begin{array}{l}\text { Adaptation to } \\
\text { climate change }\end{array}$ & Empirical & Induction & $\begin{array}{l}\text { Implicitly } \\
\text { building } \\
\text { blocks }\end{array}$ & Qualitative & Yes & $\begin{array}{l}\text { Workshops/areas } \\
\text { (9) }\end{array}$ \\
\hline $\begin{array}{l}\text { Gotgelf et al. } \\
2020\end{array}$ & $\begin{array}{l}\text { Archetypical opportunities for } \\
\text { water governance adaptation to } \\
\text { climate change }\end{array}$ & $\begin{array}{l}\text { Adaptation to } \\
\text { climate change }\end{array}$ & Meta-study & Induction & $\begin{array}{l}\text { Building } \\
\text { blocks }\end{array}$ & Mixed & Implicit & $\begin{array}{l}\text { Models (38) } \\
\text { from } 26 \\
\text { publications }\end{array}$ \\
\hline $\begin{array}{l}\text { Villamayor- } \\
\text { Tomas et al. } 2020\end{array}$ & $\begin{array}{l}\text { Are generic and specific } \\
\text { adaptation institutions always } \\
\text { relevant? An archetype analysis of } \\
\text { drought adaptation in Spanish } \\
\text { irrigation systems }\end{array}$ & $\begin{array}{l}\text { Adaptation to } \\
\text { climate change }\end{array}$ & Empirical & Induction & $\begin{array}{l}\text { Case } \\
\text { typology }\end{array}$ & Mixed & No & $\begin{array}{l}\text { Water user } \\
\text { associations (37) }\end{array}$ \\
\hline $\begin{array}{l}\text { Neudert et al. } \\
2019\end{array}$ & $\begin{array}{l}\text { Archetypes of common village } \\
\text { pasture problems in the South } \\
\text { Caucasus: insights from } \\
\text { comparative case studies in } \\
\text { Georgia and Azerbaijan }\end{array}$ & $\begin{array}{l}\text { Pasture } \\
\text { management }\end{array}$ & Empirical & $\begin{array}{l}\text { Induction/ } \\
\text { Deduction }\end{array}$ & $\begin{array}{l}\text { Building } \\
\text { blocks }\end{array}$ & Qualitative & No & Villages (6) \\
\hline $\begin{array}{l}\text { Magliocca et al. } \\
2019\end{array}$ & $\begin{array}{l}\text { Archetypical pathways of direct } \\
\text { and indirect land-use change } \\
\text { caused by Cambodia's economic } \\
\text { land concessions }\end{array}$ & Land-use change & Empirical & Induction & $\begin{array}{l}\text { Building } \\
\text { blocks }\end{array}$ & Mixed & Yes & $\begin{array}{l}\text { Land } \\
\text { concessions (30) }\end{array}$ \\
\hline Wang et al. 2019 & $\begin{array}{l}\text { Sustainable rural renewal in } \\
\text { China: archetypical patterns }\end{array}$ & Land-use change & Empirical & Induction & $\begin{array}{l}\text { Building- } \\
\text { blocks }\end{array}$ & Mixed & Implicit & $\begin{array}{l}\text { Rural } \\
\text { municipalities } \\
(27)\end{array}$ \\
\hline $\begin{array}{l}\text { Karrasch et al. } \\
2019\end{array}$ & $\begin{array}{l}\text { Land-use elements and attributed } \\
\text { ecosystem services: an archetype } \\
\text { approach to land-use evaluation at } \\
\text { the German North Sea coast }\end{array}$ & $\begin{array}{l}\text { Land-use and } \\
\text { ecosystem } \\
\text { services }\end{array}$ & Empirical & Induction & $\begin{array}{l}\text { Basis for } \\
\text { building- } \\
\text { blocs }\end{array}$ & Qualitative & No & Stakeholders (12) \\
\hline
\end{tabular}


for further studies. All three synthesis papers, together with this introduction, aim at proposing a more precise understanding of the approach, and at suggesting different directions for archetype analysis.

The more substantive and topic-related papers that follow the synthesis papers use a range of practices and approaches. It appears that any standards that may emerge from the papers depend on the kind of objectives, or possible style, of archetype analysis, which warrant different methodological decisions. The papers exemplify different kinds of objectives. Newig et al. (2019) use archetype analysis to develop a theoretical argument about sustainability pathways. Several studies work with original empirical material to identify a whole suite of archetypes to explain or sort out phenomena in their cases (Karrasch et al. 2019, Magliocca et al. 2019, Moser et al. 2019, Villamayor-Tomas et al. $2020 \mathrm{~b}$, Wang et al. 2019). Other papers identify whole suites of archetypes through meta-studies of secondary sources (Gotgelf et al. 2020, Horcea-Milcu et al. 2020, Tribaldos et al. 2020). A further set of papers use archetypes in a deductive way to design or analyze scenarios (Harrison et al. 2019, Pedde et al. 2019, Sitas et al. 2019). Neudert et al. (2019) start from a suite of archetypes identified in earlier studies in order to refine them, to diagnose patterns in a new set of cases, and to dig deeper into selected archetypes. Overall, it appears that archetype analyses can function to identify and explain patterns, or to diagnose new cases, or to develop scenarios (Oberlack et al. 2019).

In addition to methodological advances, the contributions advance understandings of sustainability issues. They range from land use, climate change adaptation, ecosystems and biodiversity, institutional failure, and socioeconomic pathways to studies of the science-policy interface (Table 2). Although each paper engages deeply with its specific field and provides multiple specific insights, their collection in the present Special Feature offers a number of overarching insights into sustainability.

First, the papers offer new insights into pathways of adaptation and transformations. Newig et al. (2019) show how institutional decline and failure can act as drivers of sustainability transformations in five surprising ways. Wang et al. (2019) demonstrate how institutional fit and decentralized governance can facilitate rural renewal in China. Villamayor-Tomas et al. (2020b) find that institutions are more relevant for adapting to drought situations when they specifically address water scarcity, compared to more generic institutions. Different institutional regime types are linked with different adaptation paths. Gotgelf et al. (2020) show that the generation of climate information through science-policy-practice partnerships may trigger transformational adaptation, e.g., through archetypical processes of learning about long-term implications of climate change.

Second, archetypes can function as boundary objects in analyses that coherently use multiple methods to examine archetypical social-ecological interactions operating at multiple scales. For example, Magliocca et al. (2019) provide a proof-of-concept analyzing the local causes and consequences of land acquisitions in Cambodia.

Third, archetypes help in formulating policy recommendations that are tailored to specific diagnoses, e.g., local financial constraints in climate change adaptation (Moser et al. 2019).
Neudert et al. (2019) show that interactions among archetypes can be crucial for deriving more refined recommendations compared to those derived from considering archetypes separately.

Fourth, scenario archetypes have supported science-policy dialogues such as in the Intergovernmental Science-Policy Platform for Biodiversity and Ecosystem Services in multiple fruitful ways. The studies suggest that a next generation of scenario archetypes might be more inductive and consider linkages of scenarios across scales in a more detailed way (Harrison et al. 2019, Pedde et al. 2019, Sitas et al. 2019).

Finally, archetypes are useful to rethink positions in sustainability research. Karrasch et al. (2019) assess stakeholder perceptions of land-use and ecosystem services to identify conflicting perspectives in participatory processes. Horcea-Milcu et al. (2020) identify points of convergence and divergence of archetypal concepts in research on sustainability transformations, and Tribaldos et al. (2020) show under which conditions intense stakeholder interactions in knowledge coproduction in different phases of research is associated with sustainable impacts.

\section{CONCLUSIONS AND OUTLOOK TO A NEW GENERATION OF ARCHETYPE ANALYSIS}

Archetype analysis is becoming an increasingly prominent approach in sustainability research. This Special Feature showcases a consolidated perspective on the multiple meanings, methods, and quality criteria of this approach and a variety of cutting-edge applications. At the same time, the collection of papers demonstrates several promising avenues for future archetype analysis. In closing, we wish to highlight three of them.

First, we have not reached established methods for conducting dynamic archetype analysis. Most of the current studies do not trace patterns over time. Yet, speaking of causality, or of a transition toward sustainability, entails considering patterns of change. This requires a clear conceptual understanding, e.g., whether to consider sequences of (static) archetypes, or archetypical sequences of system states. Common vocabularies for classification of case-specific dynamic mechanisms likely need to distinguish different time scales. Dynamic archetype analysis could also benefit from a methodological portfolio that builds on tools from scenario analysis (e.g., Rhyne 1995, Weimer-Jehle 2006, Schmid et al. 2017, Kemp-Benedict et al. 2019, Kearney 2021), or can trace patterns over time on a medium level of abstraction (e.g., Kuipers 1994, Wolstenholme 2003, Eisenack et al. 2006a, 2007, Sietz et al. 2006, Zitek et al. 2009, Reckien et al. 2011, Sietz 2014).

Second, we still need advances in transferring or scaling sustainability solutions with archetype analysis. For evidencebased insights into social-ecological similarities, e.g., if archetypes are being shared across cases, it is important to consider both geographical and social scales to ensure that solutions fit the various stakeholders' demands, preferences, and livelihood strategies, as, e.g., for replicating the zaï technique. The concept of scaling domains, i.e., regions with similar social-ecological potentials and constraints where solutions can be tested (Coe et al. 2014), might support systematic procedures for the out-scaling, transfer, replication, or adoption of successful solutions by an increasing number and range of stakeholders who operate under 
similar social-ecological conditions (Douthwaite et al. 2007). With the concept of generic leverage points for interventions (Chan et al. 2020), future archetype analysis may also spur the up-scaling (Linn 2012) of sustainability solutions or anchoring them at higher institutional levels responsible for promoting change.

Third, sustainability research currently sees many archetype studies that investigate particular phenomena separately. It is also possible that a sequence of archetype analyses discovers more details about shared phenomena of interest, and expands the set of cases where the identified archetypes hold, leading to cumulative learning. Currently, such learning is still limited, despite its recognized importance in sustainability research (Alexander et al. 2020, Newig and Rose 2020, Pauliuk 2020, Villamayor-Tomas et al. 2020a). Therefore, a next generation of archetype research may consolidate, validate, and refine knowledge about archetypes in specific domains, for instance sustainable land use, climate adaptation, and biodiversity. To this end, future studies can take up existing knowledge and unlock the potential of archetype analysis for cumulative learning about patterns of (un)sustainability.

Responses to this article can be read online at: https://www.ecologyandsociety.org/issues/responses. $\mathrm{php} / 12484$

\section{Acknowledgments:}

We thank all participants of the first and second "Research Workshops on Archetype Analysis in Sustainability Research" (University of Bern, 3-5 May 2017, and Humboldt-Universität zu Berlin, 28 February-2 March 2018) for their creative engagement in the discussions that resulted in this Special Feature. We wish to thank Norman Kearney for editorial support, and are grateful to Gerhard Petschel-Held for his deep and influential inspiration. This paper contributes to the Global Land Programme https://glp.earth.

\section{LITERATURE CITED}

Alexander, C., M. Ishikawa, M. Silverstein, M. Jacobson, I. Fiksdahl-King, and S. Angel. 1977. A pattern language: towns, buildings, construction. Oxford University Press, New York, New York, USA.

Alexander, S. M., K. Jones, N. J. Bennett, A. Budden, M. Cox, M. Crosas, E. T. Game, J. Geary, R. D. Hary, J. T. Johnson, S. Karcher, N. Motzer, J. Pittman, H. Randell, J. A. Silva, P. P. da Silva, C. Strasser, C. Strawhacker, A. Stuhl, and N. Weber. 2020. Qualitative data sharing and synthesis for sustainability science. Nature Sustainability 3(2):81-88. https://doi.org/10.1038/s41893-019-0434-8

Anstey, P. R. 2011. John Locke and natural philosophy. Oxford University Press, New York, New York, USA. https://doi. org/10.1093/acprof:oso/9780199589777.001.0001
Boyd, R. 1991. Realism, anti-foundationalism and the enthusiasm for natural kinds. Philosophical Studies 61(1):127-148. https://doi. org/10.1007/BF00385837

Carnap, R. 1956. Meaning and necessity. University of Chicago Press, Chicago, Illinois, USA.

Chan, K. M. A., D. R. Boyd, R. K. Gould, J. Jetzkowitz, J. Liu, B. Muraca, R. Naidoo, P. Olmsted, T. Satterfield, O. Selomane, et al. 2020. Levers and leverage points for pathways to sustainability. People and Nature 2(3):693-717.

Coe, R., F. Sinclair, and E. Barrios. 2014. Scaling up agroforestry requires research 'in' rather than 'for' development. Current Opinion in Environmental Sustainability 6:73-77. https://doi. org/10.1016/j.cosust.2013.10.013

Cox, M., G. Arnold, and S. V. Tomas. 2010. A review of design principles for community-based natural resource management. Ecology and Society 15(4):38. https://doi.org/10.5751/ES-03704-150438

Cox, M., S. Villamayor-Tomas, G. Epstein, L. Evans, N. C. Ban, F. Fleischman, M. Nenadovic, and G. Garcia-Lopez. 2016. Synthesizing theories of natural resource management and governance. Global Environmental Change 39:45-56. https://doi. org/10.1016/j.gloenvcha.2016.04.011

Douthwaite, B., S. Alvarez, S. Cook, R. Davies, P. George, J. Howell, R. Mackay, and J. Rubiano. 2007. Participatory impact pathways analysis: a practical application of program theory in research for development. Canadian Journal Program Evaluation 22:127-159.

Eisenack, K., M. Lüdeke, and J. Kropp. 2006a. Construction of archetypes as a formal method to analyze social-ecological systems. Proceedings of the Institutional Dimensions of Global Environmental Change Synthesis Conference 6(9).

Eisenack, K., M. Lüdecke, G. Petschel-Held, J. Scheffran, and J. Kropp. 2007. Qualitative modeling techniques to assess patterns of global change. Pages 83-127 in J. Kropp and J. Scheffran, editors. Advanced methods for decision making and risk management in sustainability science. Nova Science Publishers, Hauppauge, New York, USA.

Eisenack, K., S. Villamayor-Tomas, G. Epstein, C. Kimmich, N. Magliocca, D. Manuel-Navarrete, C. Oberlack, M. Roggero, and D. Sietz. 2019. Design and quality criteria for archetype analysis. Ecology and Society 24(3):6. https://doi.org/10.5751/ES-10855-240306

Eisenack, K., H. Welsch, and J. P. Kropp. 2006b. A qualitative dynamical modelling approach to capital accumulation in unregulated fisheries. Journal of Economic Dynamics and Control 30(12):2613-2636. https://doi.org/10.1016/j.jedc.2005.08.004

Elster, J. 2006. Nuts and bolts for the social sciences. 15th printing. Cambridge University Press, New York, New York, USA. https:// doi.org/10.1017/CBO9780511812255

Esser, H. 2002. Was Könnte Man (Heute) Unter Einer 'Theorie Mittlerer Reichweite' Verstehen? Pages 128-150 in R. Mayntz, editor. Akteure, Mechanismen, Modelle: Zur Theoriefähigkeit Makro-Sozialer Analysen. Campus Verlag, Frankfurt am Main, Germany. 
Esser, H. 2010. How far reaches the "middle range" of a theory? A reply to the comments. Sociologica 4(1):1-13. https://doi. org/10.2383/32059

Geist, H. J., and E. F. Lambin. 2004. Dynamic causal patterns of desertification. BioScience 54(9):817-829. https://doi. org/10.1641/0006-3568(2004)054[0817:DCPOD]2.0.CO:2

Gotgelf, A., M. Roggero, and K. Eisenack. 2020. Archetypical opportunities for water governance adaptation to climate change. Ecology and Society 25(4):6. https://doi.org/10.5751/es-11768-250406

Harrison, P. A., Z. V. Harmačkova, A. Aloe Karabulut, L. Brotons, M. Cantele, J. Claudet, R. W. Dunford, A. Guisan, I. P. Holman, S. Jacobs, K. Kok, A. Lobanova, A. Morán-Ordónez, S. Pedde, C. Rixen, F. Santos-Martín, M. A. Schlaepfer, C. Solidoro, A. Sonrel, and J. Hauck. 2019. Synthesizing plausible futures for biodiversity and ecosystem services in Europe and Central Asia using scenario archetypes. Ecology and Society 24 (2):27. https://doi.org/10.5751/es-10818-240227

Horcea-Milcu, A.-I., B. Martín-López, D. P. M. Lam, and D. J. Lang. 2020. Research pathways to foster transformation: linking sustainability science and social-ecological systems research. Ecology and Society 25(1):13. https://doi.org/10.5751/ES-11332-250113

Karrasch, L., T. Klenke, and M. Kleyer. 2019. Land-use elements and attributed ecosystem services: an archetype approach to landuse evaluation at the German North Sea Coast. Ecology and Society 24(2):13. https://doi.org/10.5751/ES-10744-240213

Kearney, N. M. 2021. Guided cultural evolution and sustainable development: proof of concept and exploratory results. Dissertation. University of Waterloo, Waterloo, Ontario, Canada.

Kelso, J. A. S. 1997. Dynamic patterns. MIT Press, Cambridge, Massachusetts, USA.

Kemp-Benedict, E., H. Carlsen, and S. Kartha. 2019. Large-scale scenarios as 'boundary conditions': a cross-impact balance simulated annealing (CIBSA) approach. Technological Forecasting and Social Change 143:55-63. https://doi.org/10.1016/j. techfore.2019.03.006

Keys, E., and W. J. McConnell. 2005. Global change and the intensification of agriculture in the tropics. Global Environmental Change 15(4):320-337. https://doi.org/10.1016/j.gloenvcha.2005.04.004

Kok, M., M. Lüdeke, P. Lucas, T. Sterzel, C. Walther, P. Janssen, D. Sietz, and I. de Soysa. 2016. A new method for analysing socioecological patterns of vulnerability. Regional Environmental Change 16(1):229-243. https://doi.org/10.1007/s10113-014-0746-1

Kropp, J., K. Eisenack, and J. Scheffran. 2006. Marine overexploitation: a syndrome of global change. Pages 257-84 in S. Sonak, editor. Multiple dimensions of global change. TERI, New Delhi, India.

Kuipers, B. J. 1994. Qualitative reasoning: modeling and simulation with incomplete knowledge. MIT Press, Cambridge, Massachusetts, USA.
Lambin, E. F., H. J. Geist, and E. Lepers. 2003. Dynamics of landuse and land-cover change in tropical regions. Annual Review of Environmental Resources 28(1):205-241.

Lane, D. C., and C. Smart. 1996. Reinterpreting 'generic structure': evolution, application and limitations of a concept. System Dynamics Review 12(2):87-120. https://doi.org/10.1002/(sici) 1099-1727(199622)12:2<87::aid-sdr98>3.0.c0;2-s

Linn, J. F. 2012. Scaling-up in agriculture, rural development and nutrition. International Food Policy Research Institute (IFPRI), Washington, D.C., USA.

Lüdeke, M. K. B., G. Petschel-Held, and H.-J. Schellnhuber. 2004. Syndromes of global change: the first panoramic view. GAIAEcological Perspectives for Science and Society 13(1):42-49. https://doi.org/10.14512/gaia.13.1.10

Magliocca, N. R., E. C. Ellis, G. R. Allington, A. de Bremond, J. Dell'Angelo, O. Mertz, P. Messerli, P. Meyfroidt, R. Seppelt, and P. H. Verburg. 2018. Closing global knowledge gaps: producing generalized knowledge from case studies of social-ecological systems. Global Environmental Change 50:1-14. https://doi. org/10.1016/j.gloenvcha.2018.03.003

Magliocca, N. R., Q. V. Khuc, E. A. Ellicott, and A. de Bremond. 2019. Archetypical pathways of direct and indirect land-use change caused by Cambodia's economic land concessions. Ecology and Society 24(2):25. https://doi.org/10.5751/es-10954-240225

McGinnis, M. D., and E. Ostrom. 2014. Social-ecological system framework: initial changes and continuing challenges. Ecology and Society 19(2):30. https://doi.org/10.5751/ES-06387-190230

Merton, R. 1968. Social theory and social structure. Free Press, New York, New York, USA.

Meyfroidt, P., R. R. Chowdhury, A. de Bremond, E. C. Ellis, K.H. Erb, T. Filatova, R. D. Garrett, J. M. Grove, A. Heinimann, T. Kuemmerle, et al. 2018. Middle-range theories of land system change. Global Environmental Change 53:52-67. https://doi. org/10.1016/j.gloenvcha.2018.08.006

Misselhorn, A. A. 2005. What drives food security in Southern Africa? A meta-analysis of household economy studies. Global Environmental Change 15(1): 33-43. https://doi.org/10.1016/j. gloenvcha.2004.11.003

Moser, S. C., J. A. Ekstrom, J. Kim, and S. Heitsch. 2019. Adaptation finance archetypes: local governments' persistent challenges of funding adaptation to climate change and ways to overcome them. Ecology and Society 24(2):28. https://doi. org/10.5751/es-10980-240228

Neudert, R., A. Salzer, N. Allahverdiyeva, J. Etzold, and V. Beckmann. 2019. Archetypes of common village pasture problems in the South Caucasus: insights from comparative case studies in Georgia and Azerbaijan. Ecology and Society 24(3):5. https://doi.org/10.5751/ES-10921-240305

Newig, J., P. Derwort, and N. W. Jager. 2019. Sustainability through institutional failure and decline? Archetypes of productive pathways. Ecology and Society 24(1):18. https://doi. org/10.5751/ES-10700-240118 
Newig, J., and M. Rose. 2020. Cumulating evidence in environmental governance, policy and planning research: towards a research reform agenda. Journal of Environmental Policy \& Planning 22(5):667-681. https://doi.org/10.1080/1523908x.2020.1767551

Oberlack, C., and K. Eisenack. 2018. Archetypical barriers to adapting water governance in river basins to climate change. Journal of Institutional Economics 14(3):527-555. https://doi. org/10.1017/S1744137417000509

Oberlack, C., D. Sietz, E. Bürgi-Bonanomi, A. de Bremont, J. Dell'Angelo, K. Eisenack, E. C. Ellis, G. Epstein, M. Giger, A. Heinigmann, C. Kimmich, M. T. J. Kok, D. Manuel-Navarrete, P. Messerli, P. Meyfroidt, T. Václavíc, and S. Villamayor-Tomas. 2019. Archetype analysis in sustainability research: meanings, motivations, and evidence-based policy making. Ecology and Society 24(2):26. https://doi.org/10.5751/es-10747-240226

Ostrom, E. 2007. A diagnostic approach for going beyond panaceas. Proceedings of the National Academy of Sciences 104 (39):15181-15187. https://doi.org/10.1073/pnas.0702288104

Ostrom, E. 2009. A general framework for analyzing sustainability of social-ecological systems. Science 325 (5939):419-422. https://doi.org/10.1126/science.1172133

Ostrom, E., M. A. Janssen, and J. M. Anderies. 2007. Going beyond panaceas. Proceedings of the National Academy of Sciences 104(39):15176-15178. https://doi.org/10.1073/pnas.0701886104

Pauliuk, S. 2020. Making sustainability science a cumulative effort. Nature Sustainability 3(1):2-4. https://doi.org/10.1038/ s41893-019-0443-7

Pedde, S., K. Kok, K. Hölscher, C. Oberlack, P. A. Harrison, and R. Leemans. 2019. Archetyping shared socioeconomic pathways across scales: an application to Central Asia and European case studies. Ecology and Society 24(4):30. https://doi.org/10.5751/ ES-11241-240430

Petschel-Held, G., A. Block, M. Cassel-Gintz, J. Kropp, M. K. B. Lüdeke, O. Moldenhauer, F. Reusswig, and H.-J. Schellnhuber. 1999. Syndromes of global change: a qualitative modeling approach to support environmental management. Environmental Modeling and Assessment 4(4):295-314. https://doi.org/10.1023/ a: 1019080704864

Petschel-Held, G., and M. K. B. Lüdeke. 2001. Integration of case studies on global change by means of qualitative differential equations. Integrated Assessment 2(3):123-138. https://doi. org/10.1023/a:1013379402782

Ragin, C., editor. 1987. The comparative method: moving beyond qualitative and quantitative methods. University of California Press, Berkeley, California, USA.

Reckien, D., K. Eisenack, and M. K. B. Lüdeke. 2011. Land consumption by urban sprawl - a new approach to deduce urban development scenarios from actors' preferences. Environmental Modeling and Assessment 16:465. https://doi.org/10.1007/ $\underline{\text { s10666-011-9254-6 }}$

Rhyne, R. 1995. Field anomaly relaxation: the arts of usage. Futures 27(6):657-674. https://doi.org/10.1016/0016-3287(95) 00032-R
Rudel, T. K., and J. Roper. 1997. The paths to rain forest destruction: crossnational patterns of tropical deforestation, 1975-1990. World Development 25:53-65. https://doi.org/10.1016/ S0305-750X(96)00086-1

Schmid, E., A. Pechan, M. Mehnert, and K. Eisenack. 2017. Imagine all these futures: on heterogeneous preferences and mental models in the German energy transition. Energy Research \& Social Science 27:45-56. https://doi.org/10.1016/j.erss.2017.02.012

Schneider, C. Q., and C. Wagemann. 2012. Set-theoretic methods for the social sciences - a guide to qualitative comparative analysis. Cambridge University Press, Cambridge, UK. https://doi. org/10.1017/CBO9781139004244

Senge, P. 1990. The fifth discipline: the art and practice of the learning organization. Doubleday, New York, New York, USA.

Sietz, D. 2014. Regionalisation of global insights into dryland vulnerability: better reflecting smallholders' vulnerability in northeast Brazil. Global Environmental Change 25(1):173-185. https://doi.org/10.1016/j.gloenvcha.2014.01.010

Sietz, D., U. Frey, M. Roggero, Y. Gong, N. Magliocca, R. Tan, P. Janssen, and T. Václavík. 2019. Archetype analysis in sustainability research: methodological portfolio and analytical frontiers. Ecology and Society 24(3):34. https://doi.org/10.5751/ ES-11103-240334

Sietz, D., M. K. B. Lüdeke, and C. Walther. 2011. Categorisation of typical vulnerability patterns in global drylands. Global Environmental Change 21:431-440. https://doi.org/10.1016/j. gloenvcha.2010.11.005

Sietz, D., S. E. Mamani Choque, and M. K. B. Lüdeke. 2012. Typical patterns of smallholder vulnerability to weather extremes with regard to food security in the Peruvian Altiplano. Regional Environmental Change 12(3):489-505. https://doi.org/10.1007/ s10113-011-0246-5

Sietz, D., J. C. Ordoñez, M. T. J. Kok, P. Janssen, H. B. M. Hilderink, P. Tittonell, and H. Van Dijk. 2017. Nested archetypes of vulnerability in African drylands: where lies potential for sustainable agricultural intensification? Environmental Research Letters 12(9):095006. https://doi.org/10.1088/1748-9326/aa768b

Sietz, D., B. Untied, O. Walkenhorst, M. K. B. Lüdeke, G. Mertins, G. Petschel-Held, and H. J. Schellnhuber. 2006. Smallholder agriculture in northeast Brazil: assessing heterogeneous human-environmental dynamics. Regional Environmental Change 6:132-146. https://doi.org/10.1007/ s10113-005-0010-9

Sitas, N., Z. V. Harmáčková, J. A. Anticamara, A. Arneth, R. Badola, R. Biggs, R. Blanchard, L. Brotons, M. Cantele, K. Coetzer, R. DasGupta, E. Den Belder, S. Ghosh, A. Guisan, H. Gundimeda, M. Hamann, P. A. Harrison, S. Hashimoto, J. Hauck, B. Klatt, K. Kok, R. M. Krug, A. Niamir, P. J. O'Farrell, S. Okayasu, I. Palomo, L. M. Pereira, P. Riordan, F. SantosMartín, O. Selomane, Y. Shin, and M. Valle Tobar. 2019. Exploring the usefulness of scenario archetypes in science-policy processes: experience across IPBES assessments. Ecology and Society 24(3):35. https://doi.org/10.5751/es-11039-240335 
Spash, C. L. 2012. New foundations for ecological economics. Ecological Economics 77:36-47. https://doi.org/10.1016/j. ecolecon.2012.02.004

Tribaldos, T., C. Oberlack, and F. Schneider. 2020. Impact through participatory research approaches: an archetype analysis. Ecology and Society 25(3):15. https://doi.org/10.5751/es-11517-250315

United Nations Environment Programme (UNEP). 2007. Global Environment Outlook 4. UNEP, Nairobi, Kenya. [online] URL: https://www.unep.org/resources/global-environment-outlook-4

Vidal Merino, M., D. Sietz, F. Jost, and U. Berger. 2019. Archetypes of climate vulnerability: a mixed-method approach applied in the Peruvian Andes. Climate and Development 11 (5):418-434. https://doi.org/10.1080/17565529.2018.1442804

Villamayor-Tomas, S., I. Iniesta-Arandia, and M. Roggero. $2020 b$. Are generic and specific adaptation institutions always relevant? An archetype analysis of drought adaptation in Spanish irrigation systems. Ecology and Society 25(1):32. https://doi.org/10.5751/ ES-11329-250132

Villamayor-Tomas, S., C. Oberlack, G. Epstein, S. Partelow, M. Roggero, E. Kellner, M. Tschopp, and M. Cox. 2020a. Using case study data to understand SES interactions: a model-centered meta-analysis of SES framework applications. Current Opinion in Environmental Sustainability 44:48-57. https://doi.org/10.1016/ j.cosust.2020.05.002

Wang, R., K. Eisenack, and R. Tan. 2019. Sustainable rural renewal in China: archetypical patterns. Ecology and Society 24 (3):32. https://doi.org/10.5751/ES-11069-240332

WBGU (German Advisory Council on Global Change). 1994. World in transition: basic structure of global people-environment interactions. Economica Verlag, Bonn, Germany.

Weber, M. 1922. Wirtschaft und Gesellschaft. Grundriss der Verstehenden Soziologie. Mohr Siebeck, Tübingen, Germany.

Weimer-Jehle, W. 2006. Cross-impact balances: a systemtheoretical approach to cross-impact analysis. Technological Forecasting and Social Change 73(4):334-361. https://doi. org/10.1016/j.techfore.2005.06.005

Wittgenstein, L. 1953. Philosophische Untersuchungen. Suhrkamp, Frankfurt am Main, Germany.

Wolstenholme, E. F. 2003. Towards the definition and use of a core set of archetypal structures in system dynamics. Systems Dynamics Review 19(1):7-26. https://doi.org/10.1002/sdr.259

Young, O. R. 2002. The institutional dimensions of environmental change: fit, interplay, and scale. MIT Press, Cambridge, Massachusetts, USA. https://doi.org/10.7551/mitpress/3807.001.0001

Young, O. R. 2019. Constructing diagnostic trees: a stepwise approach to institutional design. Earth System Governance 1:100002. https://doi.org/10.1016/j.esg.2019.02.001

Young, O. R., E. F. Lambin, F. Alcock, H. Haberl, S. I. Karlsson, W. J. McConnell, T. Myint, C. Pahl-Wostl, C. Polsky, P. S. Ramakrishnan, H. Schroeder, M. Scouvart, and P. H. Verburg.
2006. A portfolio approach to analyzing complex humanenvironment interactions: institutions and land change. Ecology and Society 11(2):31. https://doi.org/10.5751/ES-01799-110231

Zitek, A., S. Schmutz, S. Preis, P. Salles, B. Bredeweg, and S. Muhar. 2009. Evaluating the potential of qualitative reasoning models to contribute to sustainable catchment management. Ecological Informatics 4(5-6):381-395. https://doi.org/10.1016/j. ecoinf.2009.09.007 